\title{
Fossil Fuels Running out: Third Generation Micro Algal Biofuels Showing Light of Hope
}

\author{
Divya Srivastav', Ajay Pratap Singh², Ajay Kumar ${ }^{1 *}$ \\ ${ }^{1}$ Department of Biotechnology, Institute of Biomedical Education \& Research, Mangalayatan University, Aligarh, \\ India \\ ${ }^{2}$ Department of Agricultural Economics \& Business management, Faculty of Agricultural Sciences, \\ Aligarh Muslim University, Aligarh, India \\ Email: ${ }^{*}$ ajaymtech@gmail.com
}

Received 2 April 2014; revised 13 May 2014; accepted 26 June 2014

Copyright (C) 2014 by authors and OALib.

This work is licensed under the Creative Commons Attribution International License (CC BY).

http://creativecommons.org/licenses/by/4.0/

(c) (i) Open Access

\begin{abstract}
Fossil fuels have become the most important part of our lives and they play a very important role in our daily life. Because of increasing population and very high demands of fossil fuels, there will be shortage of these energy resources and there is a fear of depletion of these natural resources. The life is very much dependent of petrol, diesel and other fossil fuels which are being used in our daily activities and the shortage of fossil fuels is making them expensive at each and every minute, so there is a need for economical fuel. The biofuel are the solution for world's fuel problems. The biofuel are the renewable and the carbon free source of fuel which is good for environment also. The first generations by fuels produced from plants were questionable due to their conflicts with food crops and productivity of oil. The microalgae is capable of producing 10 - 100 times higher oil content than the crops producing oil. The growing and harvesting of microalgae is easier and extraction of oil from biomass is also an economical process and hence seems to be very promising future of biofuel or economical fuels.
\end{abstract}

\section{Keywords}

Micro Algal Biofuel, Third Generation Energy Source, Cultivation of Microalgae, Production of Biofuel, Recovery Process of Micro Algal Biofuel

Subject Areas: Bioengineering, Biotechnology

\section{Introduction}

The third generation bio fuels can solve the problems which were there in first generation and second generation

"Corresponding author. 
bio fuels. Ethanol and biodiesel are included in first generation biofuel, they are directly related to a biomass that is more than often edible. When the sugars $\mathrm{C}_{6}$ fermented (glucose) with a genetically modified yeast strains (Saccharomyces cerevisiae), the ethanol is produced. The feedstocks which are mostly used to form first generation biofuel (bioethanol) are corn or sugarcane and some other feedstocks like sugarbeets, barley and potato wastes. One of leading country Brazil uses sugarcane as common feedstock and the process of producing bioethanol is very simple: Crush the sugar cane in water so that sucrose is removed, then purify the sucrose to produce ethanol. The problem raised was the increased price of sugar in the market. US $\$ 0.20$ per pound was the price of sugar in August 2012 and US \$2.59 per gallon (US \$0.68/L) was ethanol price. Production of sugar was favored instead of production of bioethanol as the $1 \mathrm{~L}$ is produced out of sugar should cost around 0.30 to 0.35 . The other major source of carbohydrate, used to produce biofuels was Corn. Corn requires the hydrolyzed starch which is to liberate the sugars for ethanol fermentation with the help of an enzyme " $\alpha$-amylase", its inexpensive production of ethanol at US \$0.04 per gallon [1]. In August 2012, Corn market value was close to US \$338/t. Depending on the efficiency of process 400 to $450 \mathrm{~L}$ of ethanol was produced. Whereas the second generation biofuels are the fuels produced from different feedstocks but they are not limited to non-edible lignocellulosic biomass. It was an incentive that the price for the biomass was less as compared to the price for corn, vegetable oil and sugarcane but such biomeass was complex to be converted in the products and needed new technologies. The two different approaches were used to produce the second-generation biofuels, generally referred to as "bio" or "thermo" pathways. The second generation biofuel is produced using non-food stocks so that they can be produced at the large scale and cost is reduced as compared to the first generation biofuel as well as petroleum based fuel. It can resolve issues raised in 1st generation biofuel. It was produced by the conversion of lignocellulosic feedstocks to bioethanol, synthetic diesel and aviation fuels. The advantage of second generation biofuels over the fossil fuels and 1st generation biofuels are the low green house gas (GHG) emission, a more positive energy balance and many more. Jatropha and other seed crops are used for second generation biofuel production specially for biodiesel. Jatropha became very popular for biodiesel production in early part of the 21st century and it was praised as high yielding capacity per seed as high as 40 percent. When Jatropha was compared to soybean, which production was 15 percent then Jatropha became a miracle crop. The advantage of using Jatropha is underweighted by some disadvantages like the poor performance of engine under cold condition, the oil solidifies and clogs the fuel line of engine and the Jathropha can not produce high amount of oil if it is not properly cultivated. Its cultivation is tough for rural farmers. The hydrolysis of lignocellulosic complex is an enzymatic process which is costly at high scale production of biofuels [2]. For these regions both first and second generation biofuels were rejected.

As described above the Biofuels are classified as:

1) First-generation biofuels: They are directly related to a biomass that is edible.

2) Second-generation biofuels: They are defined as fuels produced from a wide array of different feedstock, ranging from lignocellulosic feedstocks to municipal solid wastes.

3) Third-generation biofuels: They are related to algal biomass but could to a certain extent be linked to utilization of $\mathrm{CO}_{2}$ as feedstock.

The biofuel, derived from algae has recently entered the mainstream are called third generation biofuels. It has been detected that much higher yield with lower resource input can be obtained with algae. A number of advantages can be obtained by algae. These biofuels can be generated from locally available and renewable material so it shows a significant potential for economic growth and sustainability to industrialized countries. They proved positive carbon balance with regards to fossil fuels.

The microalgae are the group of photosynthetic microorganisms which can be eukaryotic and prokaryotic both and they have the capacity of rapidly growing because of simplicity in their structure. They are being cultivated on a high scale as the producer of bio fuels which may be bio ethanol, biodiesel, bio-hydrogen and many more. Technically feasible biodiesel is that biodiesel which is produced from microalgae [3]. Other liquid fuels which are derived from petroleum can potentially be replaced by micro algal biodiesel, a renewable biodiesel. But the economics of production of biodiesel from microalgae should be improved so that the micro algal biodiesel can be sustainable as compared with petro diesel. For the production of low-cost micro algal biodiesel, algal biology improvements through genetic and metabolic engineering are required primarily. Further cost of production is lower by advancement in photo bioreactor engineering and the use of the biorefinery concept. For producing much of the micro algal biomass, the tubular photo bioreactors are used for making biodiesel. Photo bioreactors are used to achieve a controlled environment, which can give consistently good annual yield of oil produced from micro- 
algae [4]. The technologies which are currently available for micro algal $\mathrm{CO}_{2}$ fixation enhancement and the farming of microalgae can also be used for the wastewater treatment with production of biofuel [5]. The microalgae grow on water and when this process occurs in fresh water just like ponds or river then it causes challenges to marine life as well as harmful effects animal and human life also. This phenomenon is also known as eutropification in which the micro algae grow on the surface of water source and sun light cannot penetrate inside the pond or rivers and aquatic life get disturbed and when this water is taken by humans or animals then they become ill due to uptake of dirty water [6]. But somehow they can clean dirty water.

\section{Biology of Algae Is Enhanced}

The greatest impact for improving the economics of Biofuel (like biodiesel) production from microalgae are genetic engineering as well as metabolic engineering [7]. The microalgae can be treated at molecular level to produce good amount of biofuel which has potential. So a little attention is in favor of genetically modified microalgae has been seen [8]. Engineering at molecular level is in application to potentially increase in biomass yield, enabled by increase in light photosynthetic efficiency, Biomass growth rate is enhancing, Increase oil content in biomass of algae, Improve temperature tolerance to reduce the expense of cooling, Eliminate the light saturation phenomenon so that growth continues to increase in response to increasing light level, Reduce photo inhibition that actually reduces growth rate at midday light intensities that occur in temperate and tropical zones and Reduce susceptibility to photo oxidation that damages cells. The identification of possible environmental factors and biochemical triggers that might favor oil accumulation is needed. It's an important issue that engineered strains should be stable. The method to get stability also has been barely examined for microalgae [9].

\section{Farming of Microalgae and $\mathrm{CO}_{2}$ Mitigation}

Some species of microalgae can tolerate a high $\mathrm{CO}_{2}$ content in feeding air system and allow the efficient capturing of $\mathrm{CO}_{2}$ from high $\mathrm{CO}_{2}$ streams such as flaring gases $\left(\mathrm{CO}_{2}\right.$ content $\left.5 \%-15 \%\right)$ and flue gases which is the key advantage of the use of production of biofuel from microalgae [10]. Terrestrial plants absorb only $0.03 \%-0.06 \%$ $\mathrm{CO}_{2}$ so microalgae are beneficial in terms of $\mathrm{CO}_{2}$ mitigation [11]. The algal biomass can further processed for the production of biodiesel, biosyngas and bio-oil if they get different conditions [12].

1) Farming of microalgae uses waste water: Microalgae are farmed in wastewater which has a combined benefit of wastewater treatment and production of micro algae at high amount. This type of wastewater treatment, also known as the bioremediation of wastewater with the help of microalgae is beneficial in which this type of microalgae are produced and further used as the source of biofuel. If we use fresh water to grow microalgae then somehow we are destroying that water which can be used for drinking purpose on other hand if we use that water which cannot be used by any means but the farming of microalgae can be done in that water . Microalgae can remediate that water and can change that waste water into applicable water. In this type of wastewater treatment, the removal of nitrogen and phosphors from effluent takes place [13]. This would result in eutrophication if these effluents are dumped into Drinking Water Rivers or lakes [14]. Eutrophication can cause a challenge for the marine life such as the fishes, plants and humans also. The cause of Eutrophication is algae in the river and lakes. If the consumption of nitrogen and phosphorus by microalgae is in controlled manner then it would be beneficial for the environment rather than deteriorating the environment. Treatment of waste water by microalgae is also beneficial for heavy metals contaminated water treatments and it was discussed by Munoz and Guieysse [15]. But the issue is not just to grow microalgae, it should not be contaminated. The contamination is the major concern associated with farming of microalgae in wastewater [15]. The waste water can be sterilized and the sediment can be removed if all things are managed by using appropriate pretreatment technologies [16].

2) Farming of marine micro-algae: Another natural resource besides variable land is fresh water; it may cap production of biofuel. For populous countries as India, dry coastal regions like Middle East and China, the use of freshwater is particularly evident. The employment of marine microalgae for production of biofuel and mitigation of $\mathrm{CO}_{2}$ is a novel idea. The cultivation of different marine micro-algae can be studied with the use of a variety of cultivation systems which includes various types of closed photo bioreactors [17] and open ponds. Some examples of those marine microalgae species which are studied for micro algal farming are nitrogen fixing cynobacterium. Anabaena [16], red marine alga porphyridium sp. [18], marine green alga Dunaliella tertiolicta [19] and marine phytoplankter Tetraselmis suecica [20]. 


\section{Factors Necessary for Optimized Growth of Microalgae}

1) Sufficient uptake of carbon for micro algal growth: The high micro algal growth rates cannot get support with just atmospheric $\mathrm{CO}_{2}$ level, means to say that the atmospheric $\mathrm{CO}_{2}$ levels, which is $0.0387 \%$ (v/v) are not sufficient for the high micro algal growth rates as well as for the productivities needed for full-scale production of biofuel. Combustion processes of waste gases will provide $>15 \%$ (v/v) $\mathrm{CO}_{2}$ which is sufficient amounts of $\mathrm{CO}_{2}$ for production of microalgae on large-scale. The power plant flue gas is directly utilized in production systems of micro algal biofuel, for owing to the cost of upstream separation of $\mathrm{CO}_{2}$ gas [21]. Those flue gases are introduced directly into bioreactors and ponds which contain $5 \%$ to $15 \%(\mathrm{v} / \mathrm{v}) \mathrm{CO}_{2}$. These ponds or bioreactors are of various configurations and contain several species of microalgae.

2) Temperature affects growth rate of microalgae: One of the major factors that regulate morphological, cellular, and physiological responses of microalgae is temperature. The metabolic rate of microalgae is generally accelerated by higher temperatures, whereas micro algal growth is inhibited low temperatures [15]. Among micro algal species the optimal temperature varies always; however, other environmental parameters influence optimal temperatures, such as light intensity. For some species, the optimal growth temperatures are reported of $15^{\circ} \mathrm{C}-26^{\circ} \mathrm{C}$, with maximum cell densities obtained at $23^{\circ} \mathrm{C}$. Due to photosynthesis the clearly favorable effects on micro algal growth rates were observed only in daytime at higher temperatures, except when the temperature is as low as $7^{\circ} \mathrm{C}$ at when the night [22].

3) Microalgae require some other Nutrients: Nitrogen is the most important element, required as micro algal nutrient apart from carbon [22] and nitrogen is directly associated with the primary metabolism of microalgae as it is constituent of both proteins and nucleic acids. As a primary nitrogen source ammonium is preferred by fast growing species of microalgae rather than nitrate [24], micro algal growth will be enhanced if a medium that lacks nitrate is used [25]. As expected the microalgae grow at lower rates under partial nitrogen deprivation, but at the expense of lower productivities significantly more lipids are produced, which are synthesized under stress conditions as reserve compounds [26]. Phosphorus is the third most important nutrient.

4) Provision of light: The basic energy source is light for phototrophic microorganisms. Thus the end utilization efficiency and intensity of the light supplied are the most important in micro algal bioreactors. The micro algal bioreactor should be designed in such a way to the issue of optical depth which can measure the proportion of radiation scattered along a path or absorbed through a partially transparent medium [27] because it has been studied that the light intensity decreases in high-density cultures and intensity of light is decreased within the deeper culture medium also.

5) Energy harvesting: The most common source of energy for microalgae is Sunlight, to an extent that is rather species-dependent. Micro algal productivity increases with the increment in light conversion efficiency when light are the only limiting factor [28]. Although as compared with those of higher plants, the required light intensity of typical microalgae is relatively low. With the increment of light intensity up to $400 \mathrm{~m} \cdot \mathrm{mol} \cdot \mathrm{m}^{-2} \cdot \mathrm{s}^{-1}$, micro algal activity usually rises [15], if we take an example of Chlorella and Scenedesmus sp. the saturating light intensity of this in the order of $200 \mathrm{~m} \cdot \mathrm{mol} \cdot \mathrm{m}^{-2} \cdot \mathrm{s}^{-1}$ [29]. Many micro algal species can switch to heterotrophic growth from phototrophic, and some can even grow mixotrophically in which energy is produced by using photosynthesis, but biosynthesis is carried out by organic carbon compounds.

\section{Some Selective Cost-Effective Biomass Harvesting Technology}

There are some technologies which have been investigated for harvesting micro algal biomass and these technologies are biological flocculation [30], chemical flocculation [31], filtration [32], centrifugation [33] and ultrasonic aggregation [34]. The biological and chemical flocculation require low operating cost but they both have the disadvantage of time consuming nature for processing and have the risk of the decomposition of bioreactive products also. But other like filtration, centrifugation and ultrasonic aggregation techniques are more effective and costly too. On the basis of the value of target product, the required micro algal cell size and the product concentration, one can choose the appropriate harvesting technique.

\section{Toxic Compounds for Microalgae}

Various gases, such as $\mathrm{CO}_{2}, \mathrm{SO}_{\mathrm{X}}, \mathrm{NO}_{\mathrm{X}}, \mathrm{NH}_{3}$ and $\mathrm{O}_{2}$ and heavy metals may be toxic to microalgae. Among micro algal species the optimal $\mathrm{CO}_{2}$ concentrations vary greatly. When common freshwater microalgae are grown 
under high $\mathrm{CO}_{2}$ concentrations then they exhibit changes in photosynthetic characteristics [above $5 \%(\mathrm{v} / \mathrm{v})$ ]. These changes include higher photosynthetic sensitivity to $\mathrm{O}_{2}$, lower affinity to $\mathrm{CO}_{2}$, lower activity of carbonic anhydrase and higher $\mathrm{CO}_{2}$ compensation points [35].

\section{Metabolic Engineering Applied on Algae}

Although routine manipulation on genetic level is different for all microalgae, only some micro algal strain can be genetically manipulated (like Chlamydomonas reinhardtii, the diatom Haeodactylum tricornutum and Volvox carteri). The new model systems and the new techniques will be developed as the interest in algal biofuel is being expanded. Previously the algal transgenics have been reviewed [36] however, because of recent seminal studies the "molecular toolkit" has since expanded. Some of the significant advances include: 1) Transgene expressions in an efficient way [37]. 2) Riboswitches are used for gene regulation in algae as a novel mechanism [38]. 3) Inducible luciferase reporter genes and nuclear promoters [39]. 4) Expression of inducible chloroplast gene [40].

In green algae the metabolic pathways are related to biohydrogen and biofuel production. The light-harvesting complex which is bound to carotenoids and chlorophyll capture light energy as photons in green algae. In the catalytic oxidation of water the Photo system II uses this energy, forms molecular $\mathrm{O}_{2}$, protons and electrons. The formation of NADPH from the reduction of ferredoxin is leaded by the photosynthetic electron transport chain which transfers Low-potential electrons. After water oxidation into the thylakoid lumen the protons are released so an electrochemical gradient is formed and this electrochemical gradient is used to drive ATP production via ATP synthase. The substrates for the Calvin-Benson cycle are the photosynthetic products which are NADPH and ATP. Inorganic $\mathrm{CO}_{2}$ is fixed into 3-C molecules that are assimilated into the starch, lipids, sugars or other molecules required for cellular growth in the Calvin-Benson cycle [36].

\section{Biohydrogen and Biofuel Production from Engineered Algae}

Eukaryotic algae is utilized as it has an interest for the renewable bioenergy carriers production, including alcohols from starches, diesel fuel surrogates from lipids, and fuel cells from $\mathrm{H}_{2}$. If the relation is studied for the terrestrial biofuel feed stocks, the solar energy can be converted into fuels by algae at higher photosynthetic efficiencies, which can thrive in salt water systems. Recently, a considerable progress is seen in identification of relevant pathways and bioenergy genes in microalgae. Some strains are being engineered with the powerful techniques on genetic level via the targeted disruption of transgene expression and/or endogenous genes [41].

\section{Advanced Photo Bioreactors and Design}

Another key aspect for efficiency and cost effectiveness of the production process of micro algal biofuel is the cultivation system. The process parameter was focused by Pulz [42], who suggested a number of open systems also. Some new systems were examined and useful diagrams of discussed closed systems were offered by Janssen et al. [43]. He used optical fibers for enhancement of lighting. Currently, due to low capital cost the open pond systems are been preferred for the commercial cultivation of microalgae on the other hand closed systems provide better control condition over chances of contamination, mass transfer and other cultivation conditions. The closed photo bioreactor and open pond combines and open pond combines and this combination is beneficial for the two, it is effective at a 2-ha scale [44].

\section{Drying of Biomass}

Before thermo chemical processing and/or bioproduct extraction another considerable step takes place which is biomass drying. The cheapest drying method which has been employed is the sun drying method [45]. However sun drying method is time consuming method and a large drying surface is required for this type of drying technique. The loss of some bioreactive products is the risk in sun drying method. Another low cost drying technology has been investigated that is low-pressure-shelf drying technique [46]. Its efficiency is low. Some techniques have been investigated as more effective and more costly also, which are Drum Drying [47], Spray Drying [48], fluidized bed drying [48], freeze drying and window dehydration technology [49]. The net energy output of the fuel can be maximized if the drying efficiency and cost-effectiveness are balanced. 


\section{Biorefinery: Recovery of Biofuel}

The production of a wide range of chemicals and biofuel from biomass by the integration of bioprocessing in a cost-effective manner is termed as biorefinery. The production of biofuel from biomass is done by appropriate low environmental impact chemical technology. The biorefinery is in environmentally sustainable manner [50]. For example fermentation of ethanol produced from sugar derived from cellulose and semi-cellulose [51], biosyngas and bio-oils by gasification of woods or other type of biomass [52]. Not only biofuel but an array of useful products can be produced by microalgae which are healthy food, pharmaceutical compounds and natural pigments [53]. The strategy of a high-value co product should enhance the economical feasibility of production of micro algal biofuel. It involves $\mathrm{CO}_{2}$ mitigation as the micro algal framing facility for the cultivation of microalgae. This process is followed by bioreactive products from harvested algal biomass are extracted out. Thermal processing includes pyrolysis, liquefaction or gasification, Extraction of high-value chemicals from the resulting liquid, vapor and/or solid phases, Reforming/upgrading biofuel for different applications. The main methods of disruption of cell and isolation of algal oil from cells include bead mills method [54], presses (like screw, expeller and piston) [55], solvent extraction using hexane and cavitation using pressure differences [56]. Some of the less known methods include osmotic shock, super critical $\mathrm{CO}_{2}$ extraction, chemical and enzymatic lysis. However these less known methods cannot be used for industrial production because of their processing cost.

\section{Thermo Chemical Liquefaction}

It is the alternative method for obtaining the higher amount of liquid fuel. With this process the other compounds in the cell like protein and fiber can be converted to liquid fuel. The thermo chemical liquefaction is performed between the $200^{\circ} \mathrm{C}-300^{\circ} \mathrm{C}$, the catalyst may be present or absent [57]. The autoclaving is done at 20 - $30 \mathrm{mPa}$. The advantage of thermo chemical liquefaction is that it can treat the wet materials also. The materials with up to $60 \%$ water can be treated in this process which allows it to escape the drying process [58]. The highest yield is achieved at $300^{\circ} \mathrm{C}$ and when temperature raises more than $300^{\circ} \mathrm{C}$ the thermo chemical degradation take place. A series of steps is applied for the reaction mixture separation in liquefaction. $\mathrm{CO}_{2}$ is sent back for collection in the process, solvent extraction method is used to separate oil and water. The oil is separated from solvent by the process of evaporation under low pressure and temperature [57].

\section{Conversion of Crude Oil to Bio Diesel}

The conversion of crude oil to bio diesel involves various steps like pre treatment of crude oil for removal of fatty acids and degumming which also eliminates phosphorus content. Degumming is used for the removal of phospholipids by using very small amounts of water [59], acetic anhydride [55], through ultrafiltration [60] and distillation [59]. Purification of fatty acids with the help of transesterification using base catalyst and methanol. The conversion is higher if the process is run for a longer time, for the process of 20 hours the conversion increased up to $85 \%$ from $65 \%$ [61]. Various catalysts are also used for altering the rate of transesterification like ferric sulphate [62]. In the process of transesterification in a homogenous phase reaction the base catalysts used are either sodium hydroxide or potassium hydroxide. The several methods used for transesterification include heterogeneous catalyst [63] and supercritical methanol [64]. Butanol is widely used as the biofuel which is now produced chemically and biologically [65].

\section{Issues of Third Generation Biofuel}

The impact on greenhouse gases and the net yield of energy are the most controversial issues of third generation biofuels. The yield of biofuels depends on the algal metabolism. It is important that the produced micro algal biodiesel is ecumenically competitive to replace the fossil fuels [66]. The enhanced photosynthesis efficiency is also a major part of issue. The efficiency of conversion of starch though photosynthesis can be increased by reducing the number of chlorophyll-binding LHC proteins in the strain which are in deeper habitat means do not live on water surface. This is a natural strategy which is found in nature [67]. Now this is the challenge to engineer those algal cells which have a reduces LHC antenna and grow on water surface.

The improved metabolism of micro algal population is also an issue to gain high potential yield and quality of the microalgal biomas. Genetically modified strains can solve all problems. Identify the gene responsible for lipid synthesis and introduce them in the algal cells can improve the production and energy gain [68]. The bio- 
diesel produced from the processing of microalgae differs from other forms of biodiesel in the content of polyunsaturated fats. Polyunsaturated fats are known for their ability to retain fluidity at lower temperatures [69]. While this may seem like an advantage in production during the colder temperatures of the winter, the polyunsaturated fats result in lower stability during regular seasonal temperatures [70]. Different types of bioreactors are used for the better production of biofuels [71] [72]. Bubbling $\mathrm{CO}_{2}$ through algal cultivation systems can greatly increase productivity and yield [74]. Ponds are in use for large scale production of biofuels from microalgae [75].

\section{Conclusion}

Biofuels are produced from the renewable source and are the sustainable energy source and are also $\mathrm{CO}_{2}$ neutral. The first generation of biofuel was not satisfactory due to the less oil yield and impact on food crops. The third generation biofuel from microalgae seem to rule out the problem of low yield and proving to be very useful. They are becoming economical, cost effective and easily available energy source without harming environment. The fossil fuel are in limited amount so we have to search the alternative energy sources and micro algal biofuel looking as a very promising player in this regard but after all these promises there is still a need for improvement and more research needs to be done which will surely be helpful in mankind.

\section{Future Aspects}

The limited amount of fossil fuels and the increasing fuel demands are big problem in today's world. It is not possible to fulfill the energy demands using fossil fuels as they are non-renewable and exhaustible source of fuel so there is a need to look for alternative source of fuel. Microalgae have provided a very big renewable source of fuel. The future of micro algal biofuel seems to be very bright considering that fossil fuels are decreasing very rapidly. The increasing demands of fossil fuels has resulted in the price hike of these so micro algal biofuel seem to serve as an economical source of biofuel.

\section{Acknowledgements}

The authors are grateful to Dean, I.B.M.E.R, Mangalayatan University Aligarh, India) for providing necessary facilities and encouragement. They are also thankful to all faculty members of the Institute of Biomedical Education and Research, Mangalayatan University Aligarh, India for their generous help and suggestions during the paper preparation.

\section{References}

[1] McAloon, A., Taylor, F., Yee, W., Ibsen, K. and Wooley, R. (2000) Determining the Cost of Producing Ethanol from Corn Starch and Lignocellulosic Feedstocks. National Renewable Energy Laboratory, Golden.

[2] Second Generation Biofuels: An Unproven Future Technology with Unknown Risks.

[3] Li, Y.Q., et al. (2008) Biofuels from Microalgae. Biotechnology Progress, 24, 815-820.

[4] Ugwu, C.U., Aoyagi, H. and Uchiyama, H. (2008) Photobioreactors for Mass Cultivation of Algae. Bioresource Technology, 99, 4021-4028. http://dx.doi.org/10.1016/j.biortech.2007.01.046

[5] IPCC (2007) Intergovernmental Panel on Climate Change “AR4 Synthesis report”. www.ipcc.ch

[6] Benemann, J.R. (2008) Opportunities \& Challenges in Algae Biofuels Production in Line with Algae World.

[7] Dunahay, T.G., Jarvis, E.E., Dais, S.S. and Roessler, P.G. (1996) Manipulation of Microalgal Lipid Production Using Genetic Engineering. Humana Press, New York, 223-231.

[8] León-Bañares, R., González-Ballester, D., Galváan, A. and Fernández, E. (2004) Transgenic Microalgae as Green CellFactories. Trends in Biotechnology, 22, 45-52. http://dx.doi.org/10.1016/j.tibtech.2003.11.003

[9] Chisti, Y. (2007) Biodiesel from Microalgae. Biotechnology Advances, 25, 294-306. http://dx.doi.org/10.1016/j.biotechadv.2007.02.001

[10] Hsueh, H.T., Chu, H. and Yu, S.T. (2007) A Batch Study on the Bio-Fixation of Carbon Dioxide in the Absorbed Solution from a Chemical Wet Scrubber by Hot Spring and Marine Algae. Chemosphere, 66, 878-886. http://dx.doi.org/10.1016/j.chemosphere.2006.06.022

[11] Vunjak-Novakovic, G., Kim, Y., Wu, X., Berzin, I. and Merchuk, J.C. (2005) Air-Lift Bioreactors for Algal Growth on 
Flue Gas: Mathematical Modeling and Pilotplant Studies. Industrial \& Engineering Chemistry Research, 44, 61546163. http://dx.doi.org/10.1021/ie049099z

[12] Lee, J.N., Lee, J.S., Shin, C.S., Park, S.C. and Kim, S.W. (2000) Methods to Enhance Tolerances of Chlorella KR-1 to Toxic Compounds in Flue Gas. Applied Biochemistry and Biotechnology, 84-86, 329-342. http://dx.doi.org/10.1385/ABAB:84-86:1-9:329

[13] Abdel Hameed, M.S. (2007) Effect of Algal Density in Bead, Bead Size and Bead Concentrations on Wastewater Nutrient Removal. African Journal of Biotechnology, 6, 1185-1191.

[14] Galvez-Cloutier, R., Leroueil, S., Allier, D., Locat, J. and Arsenault, S. (2006) A Combined Method: Precipitation and Capping, to Attenuate Eutrophication in Canadian Lakes. Journal of ASTM International, 3.

[15] Munoz, R. and Guieysse, B. (2006) Algal-Bacterial Processes for the Treatment of Hazardous Contaminants: A Review. Water Research, 40, 2799-2815. http://dx.doi.org/10.1016/j.watres.2006.06.011

[16] Tamer, E., Amin, M.A., Ossama, E.T., Bo, M. and Benoit, G. (2006) Biological Treatment of Industrial Wastes in a Photobioreactor. Water Science and Technology, 53, 117-125. http://dx.doi.org/10.2166/wst.2006.344

[17] Blanco, A.M., Moreno, J., Del Campo, J.A., Rivas, J. and Guerrero, M.G. (2007) Outdoor Cultivation of Lutein-Rich Cells of Muriellopsis sp. in Open Ponds. Applied Microbiology and Biotechnology, 73, 1259-1266. http://dx.doi.org/10.1007/s00253-006-0598-9

[18] Wu, X. and Merchuk, J.C. (2004) Simulation of Algae Growth in a Bench Scale Internal Loop Airlift Reactor. Chemical Engineering Science, 59, 2899-2912. http://dx.doi.org/10.1016/j.ces.2004.02.019

[19] Janssen, M., Slenders, P., Tramper, J., Mur, L.R. and Wijffels, R.H. (2001) Photosynthetic Efficiency of Dunaliella tertiolecta under Short Light/Dark Cycles. Enzyme and Microbial Technology, 29, 298-305. http://dx.doi.org/10.1016/S0141-0229(01)00387-8

[20] Laws, E.A. and Berning, J.L. (1991) A Study of the Energetics and Economics of Micro Algal Mass Culture with the Marine Chlorophyte Tetraselmis suecica: Implications for Use of Power Plant Stack Gases. Biotechnology and Bioengineering, 37, 936-947. http://dx.doi.org/10.1002/bit.260371007

[21] Lackne, K.S. (2003) Climate Change: A Guide to $\mathrm{CO}_{2}$ Sequestration. Science, 300, 1677-1678. http://dx.doi.org/10.1126/science.1079033

[22] Tamiya, H. (1957) Mass Culture of Algae. Annual Review of Plant Physiology, 8, 309-334. http://dx.doi.org/10.1146/annurev.pp.08.060157.001521

[23] Becker, E.W. (1994) Microalgae Biotechnology and Microbiology. Cambridge University Press, Cambridge.

[24] Green, B.R. and Durnford, D.G. (1996) The Chlorophyll-Carotenoid Proteins of Oxygenic Photosynthesis. Annual Review of Plant Physiology and Plant Molecular Biology, 47, 685-714. http://dx.doi.org/10.1146/annurev.arplant.47.1.685

[25] Jin, H.F., Lim, B.R. and Lee, K. (2006) Influence of Nitrate Feeding on Carbon Dioxide Fixation by Microalgae. Journal of Environmental Science and Health, Part A: Toxic/Hazardous Substances and Environmental Engineering, 41, 2813-2824. http://dx.doi.org/10.1080/10934520600967928

[26] Lardon, L., Hélias, A., Sialve, B., Steyer, J.P. and Bernard, O. (2009) Life-Cycle Assessment of Biodiesel Production from Microalgae. Environmental Science, Technology, 43, 6475-6481. http://dx.doi.org/10.1021/es900705j

[27] Suh, I.S. and Lee, S.B. (2003) A Light Distribution Model for an Internally Radiating Photobioreactor. Biotechnology and Bioengineering, 82, 180-189. http://dx.doi.org/10.1002/bit.10558

[28] Richmond, A., Zhang, C.W. and Zarmi, Y. (2003) Efficient Use of Strong Light for High Photosynthetic Productivity: Interrelationships between the Optical Path, the Population Density and the Cell-Growth Inhibition. Biomolecular Engineering, 20, 229-236. http://dx.doi.org/10.1016/S1389-0344(03)00060-1

[29] Hanagata, N., Takeuchi, T., Fukuju, Y., Barnes, D.J. and Karube, I. (1992) Tolerance of Microalgae to High $\mathrm{CO}_{2}$ and High Temperature. Phytochemistry, 31, 3345-3348. http://dx.doi.org/10.1016/0031-9422(92)83682-O

[30] Divakaran, R. and Pillai, V.N.S. (2002) Flocculation of Algae Using Chitosan. Journal of Applied Phycology, 14, 419422. http://dx.doi.org/10.1023/A:1022137023257

[31] Knuckey, R.M., Brown, M.R., Robert, R. and Frampton, D.M.F. (2006) Production of Microalgal Concentrates by Flocculation and Their Assessment as Aquaculture Feeds. Aquacultural Engineering, 35, 300-313. http://dx.doi.org/10.1016/j.aquaeng.2006.04.001

[32] Grima, E.M., Belarbi, E.H., Fernández, F.G.A., Medina, A.R. and Chisti, Y. (2003) Recovery of Microalgal Biomass and Metabolites: Process Options and Economics. Biotechnology Advances, 20, 491-515. http://dx.doi.org/10.1016/S0734-9750(02)00050-2

[33] Olaizola, M. (2003) Commercial Development of Microalgal Biotechnology: From the Test Tube to the Marketplace. Biomolecular Engineering, 20, 459-466. http://dx.doi.org/10.1016/S1389-0344(03)00076-5 
[34] Bosma, R., van Spronsen, W.A., Tramper, J. and Wijffels, R.H. (2003) Ultrasound, a New Separation Technique to Harvest Microalgae. Journal of Applied Phycology, 15, 143-153. http://dx.doi.org/10.1023/A:1023807011027

[35] Yang, Y. and Gao, K. (2003) Effects of $\mathrm{CO}_{2}$ Concentrations on the Freshwater Microalgae Chlamydomonas reinhardtii, Chlorella pyrenoidosa and Scenedesmus obliquus (Chlorophyta). Journal of Applied Phycology, 15, 379-389. http://dx.doi.org/10.1023/A:1026021021774

[36] Walker, T.L., Collet, C. and Purton, S. (2005) Algal Transgenics in the Genomic Era. Journal of Phycology, 41, 10771093. http://dx.doi.org/10.1111/j.1529-8817.2005.00133.x

[37] Neupert, J., Karcher, D. and Bock, R. (2008) Generation of Chlamydomonas Strains That Efficiently Express Nuclear Transgenes. The Plant Journal, 57, 1140-1150. http://dx.doi.org/10.1111/j.1365-313X.2008.03746.X

[38] Croft, M.T., Moulin, M., Webb, M.E. and Smith, A.G. (2007) Thiamine Biosynthesis in Algae Is Regulated by Riboswitches. Proceedings of the National Academy of Sciences of the United States of America, 104, 20770-20775. http://dx.doi.org/10.1073/pnas.0705786105

[39] Shao, N. and Bock, R. (2008) A Codon-Optimized Luciferase from Gaussia princeps Facilitates the in Vivo Monitoring of Gene Expression in the Model Alga Chlamydomonas reinhardtii. Current Genetics, 53, 381-388. http://dx.doi.org/10.1007/s00294-008-0189-7

[40] Surzycki, R., Cournac, L., Peltier, G. and Rochaix, J.D. (2007) Potential for Hydrogen Production with Inducible Chloroplast Gene Expression in Chlamydomonas. Proceedings of the National Academy of Sciences of the United States of America, 104, 17548-17553. http://dx.doi.org/10.1073/pnas.0704205104

[41] Stripp, S.T., Goldet, G., Brandmayr, C., Sanganas, O., Vincent, K.A., Haumann, M., Armstrong, F.A. and Happe, T. (2009) How Oxygen Attacks [FeFe] Hydrogenases from Photosynthetic Organisms. Proceedings of the National Academy of Sciences of the United States of America, 106, 17331-17336. http://dx.doi.org/10.1073/pnas.0905343106

[42] Pulz, O. (2001) Photobioreactors: Production Systems for Phototrophic Microorganisms. Applied Microbiology and Biotechnology, 57, 287-293. http://dx.doi.org/10.1007/s002530100702

[43] Janssen, M., Tramper, J., Mur, L.R. and Wijffels, R.H. (2003) Enclosed Outdoor Photobioreactors: Light Regime, Photosynthetic Efficiency, Scale-Up, and Future Prospects. Biotechnology and Bioengineering, 81, 193-210. http://dx.doi.org/10.1002/bit.10468

[44] Huntley, M.E. and Redalje, D.G. (2007) $\mathrm{CO}_{2}$ Mitigation and Renewable Oil from Photosynthetic Microbes: A New Appraisal. Mitigation and Adaptation Strategies for Global Change, 12, 573-608. http://dx.doi.org/10.1007/s11027-006-7304-1

[45] Millamena, O.M., Aujero, E. and Borlongan, I.G. (1990) Techniques on Algae Harvesting and Preservation for Use in Culture and as Larval Food. Aquacultural Engineering, 9, 295-304. http://dx.doi.org/10.1016/0144-8609(90)90022-R

[46] Prakash, J., Pushparaj, B., Carlozzi, P., Torzillo, G., Montaini, E. and Materassi, R. (1997) Micro Algal Biomass Drying by a Simple Solar Device. International Journal of Solar Energy, 18, 303-311. http://dx.doi.org/10.1080/01425919708914325

[47] Desmorieux, H. and Decaen, N. (2006) Convective Drying of Spirulina in Thin Layer. Journal of Food Engineering, 77, 64-70. http://dx.doi.org/10.1016/j.jfoodeng.2005.05.060

[48] Leach, G., Oliveira, G. and Morais, R. (1998) Spray-Drying of Dunaliella salina to Produce a $\beta$-Carotene Rich Powder. Journal of Industrial Microbiology and Biotechnology, 20, 82-85. http://dx.doi.org/10.1038/sj.jim.2900485

[49] Nindo, C.I. and Tang, J. (2007) Refractance Window Dehydration Technology: A Novel Contact Drying Method. Drying Technology, 25, 37-48. http://dx.doi.org/10.1080/07373930601152673

[50] Chisti, Y. (2007) Biodiesel from Microalgae. Biotechnology Advances, 25, 294-306. http://dx.doi.org/10.1016/j.biotechadv.2007.02.001

[51] (2007) Company News: Biodiesel from Algae Makes Debut. Fuels \& Lubes International, 13, 28.

[52] Mohan, D., Pittman Jr., C.U. and Steele, P.H. (2006) Pyrolysis of Wood/Biomass for Bio-Oil: A Critical Review. Energy Fuels, 20, 848-889. http://dx.doi.org/10.1021/ef0502397

[53] Oh, H.M., Choi, A. and Mheen, T.I. (2003) High-Value Materials from Microalgae. Korean Journal of Microbiology and Biotechnology, 31, 95-102.

[54] Chisti, Y. and Murray, M.Y. (1986) Disruption of Microbial Cells for Intracellular Products. Enzyme and Microbial Technology, 8, 194-204. http://dx.doi.org/10.1016/0141-0229(86)90087-6

[55] Swern, D. (1982) Bailey’s Industrial Oil and Fat Products. 4th Edition, Vol. 2, Wiley-Interscience, Hoboken.

[56] Moholkar, V.S. and Pandit, A.B. (2001) Numerical Investigations in the Behaviour of One-Dimensional Bubbly Flow in Hydrodynamic Cavitations. Chemical Engineering Science, 56, 1411-1418.

http://dx.doi.org/10.1016/S0009-2509(00)00365-1 
[57] Sawayama, S., Minowa, T. and Yokoyama, S.Y. (1999) Possibility of Renewable Energy Production and $\mathrm{CO}_{2} \mathrm{Mitiga-}^{-}$ tion by Thermochemical Liquefaction of Microalgae. Biomass and Bioenergy, 17, 33-39. http://dx.doi.org/10.1016/S0961-9534(99)00019-7

[58] Dote, Y., Sawayama, S., Inoue, S., Minowa, T. and Yokoyama, S. (1994) Recovery of Liquid Fuel from HydrocarbonRich Microalgae by Thermochemical Liquefaction. Fuel, 73, 1855-1857. http://dx.doi.org/10.1016/0016-2361(94)90211-9

[59] Appelqvist, L.A. and Ohlson, R. (1972) Rapeseed (-Cultivation, Composition, Processing and Utilization). Elsevier Publishing Company, Amsterdam.

[60] Subramanian, R. and Nakajima, M. (1997) Membrane Degumming of Crude Soybean and Rapeseed Oils. Journal of the American Oil Chemists' Society, 74, 971-975.

[61] Park, Y.M., Lee, D.W., Kim, D.K., Lee, J.S. and Lee, K.Y. (2008) The Heterogeneous Catalyst System for the Continuous Conversion of Free Fatty Acids in Used Vegetable Oils for the Production of Biodiesel. Catalysis Today, 131, 238-243. http://dx.doi.org/10.1016/j.cattod.2007.10.052

[62] López, D.E., Goodwin Jr., J.G., Brucea, D.A. and Furuta, S. (2008) Esterification and Transesterification Using Modified-Zircona Catalysts. Applied Catalysis A: General, 339, 76-83. http://dx.doi.org/10.1016/j.apcata.2008.01.009

[63] Shibasaki-Kitakawa, N., Honda, H., Kuribayashi, H., Toda, T., Fukumura, T. and Yonemoto, T. (2007) Biodiesel Production Using Anionic Ion-Exchange Resin as Heterogenous Catalyst. Bioresource Technology, 98, 416-421. http://dx.doi.org/10.1016/j.biortech.2005.12.010

[64] Gryglewicz, S. (1999) Rapeseed Oil Methyl Esters Preparation Using Heterogeneous Catalysts. Bioresource Technology, 70, 249-253. http://dx.doi.org/10.1016/S0960-8524(99)00042-5

[65] Jain, S., Yadav, M.K. and Kumar, A. (2013) Production of Butanol: A Biofuel. 255-280.

[66] Quintana, N., et al. (2011) Renewable Energy from Cyanobacteria: Energy Production Optimization by Metabolic Pathway Engineering. Applied Microbiology and Biotechnology, 91, 471-490. http://dx.doi.org/10.1007/s00253-011-3394-0

[67] Chellapandim, P., Prabaharan, D. and Uma, L. (2010) Evaluation of Methanogenic Activity of Biogas Plant Slurry for Monitoring Codigestion of Ossein Factory Wastes and Cyanobacterial Biomass. Applied Biochemistry and Biotechnology, 162, 524-535. http://dx.doi.org/10.1007/s12010-009-8834-2

[68] Luo, D., Hu, Z., Choi, D.G., Thomas, V.M., Realff, M.J. and Chance, R.R. (2010) Life Cycle Energy and Greenhouse Gas Emissions for an Ethanol Production Process Based on Blue-Green Algae. Environmental Science \& Technology, 44, 8670-8677. http://dx.doi.org/10.1021/es1007577

[69] Arumugam, M., Agarwal, A., Arya, M.C. and Ahmed, Z. (2013) Influence of Nitrogen Sources on Biomass Productivity of Microalgae Scenedesmus bijugatus. Bioresource Technology, 131, 246-249. http://dx.doi.org/10.1016/j.biortech.2012.12.159

[70] (2013) Algae to Crude Oil: Million-Year Natural Process Takes Minutes in the Lab, PNNL.

[71] (2012) Accelerating the Uptake of CCS: Industrial Use of Captured Carbon Dioxide. Global CCS Institute.

[72] De Grasse Tyson, N. (2013) PBS Online. Algae Biofuel.

[73] Nathan (2013) Breakthrough in Microalgae Oil Production, Accelerated Ability to Produce Variety of Different Oils. CleanTechnica.

[74] Arumugam, M., Agarwal, A., Arya, M.C. and Ahmed, Z. (2013) Influence of Nitrogen Sources on Biomass Productivity of Microalgae Scenedesmus bijugatus. Bioresource Technology, 131, 246-249. http://dx.doi.org/10.1016/j.biortech.2012.12.159

[75] (2013) Government of Canada Investing in Technology to Reduce GHG Emissions in the Oil Sands-National Research Council Canada. Nrc-cnrc.gc.ca. 